\title{
Notícias da Conferência, que a Academia Real da História Portuguesa fez em 22 de setembro de 1730*
}

\author{
José da Cunha Brochado
}

O Conde da Ericeira foi Diretor desta Conferência, porque o Marquês de Alegrete, a quem tocava a direção, se não achou nela, por estar de semana assistindo o Príncipe nosso Senhor.

Logo que se distribuíram as Notícias das Conferências antecedentes, se empregou o tempo desta em se ouvir com geral aplauso de todos os Acadêmicos um douto papel, que José da Cunha Brochado leu, o qual se daria impresso separadamente, senão fora o mais nobre, e mais principal corpo destas Notícias.

O maior ponto duvidoso, de que devo dar conta, ou a maior dúvida da História, a que não sei responder, é a mesma História; parece que na História não há verdade, ou que a verdade não é necessária na História. Não permita a docilidade Acadêmica extrair-se de si mesma, negando a sua benévola audiência o breve exame de um paradoxo, que nem é novo, nem é inútil.

Seja Clio, ou Saturno, o inventor da História, seja arte, ou seja ciência, vulgarmente se descreve: Rerum gestarum cum laude, aut vituperio narratio; ${ }^{1}$ ou se define mais amplamente Cognitio singularium, quorum memoriam conservari utile fit ad bene, beateque vivendum; ${ }^{2}$ de que dizem ser fundamento, alma e condição a verdade dos fatos referidos. ${ }^{3}$ Acredita-se esta necessária condição, pela etimologia da mesma palavra, que significa propriamente a narração das coisas que, o Escritor viu por seus olhos. A eleição da matéria, a distribuição, a advertência escrupulosa para separar as coisas, que não convêm à dignidade da História, e à sua final instrução, sem injúria do grave, e do honesto, são a primeira regra do estudo, e do respeito de um Historiador; a dificuldade porém de achar a verdade, de querer achá-la, e de querer dizê-la, é superior, segundo parece, a todo o respeito, e a todo o estudo.

A verdade, sendo de sua natureza tão escondida dos homens, nada é mais difícil, que fazer conhecê-la aos mesmos homens. Demócrito dizia, que a

\footnotetext{
${ }^{1}$ Transcrição realizada por Pedro Telles da Silveira a partir do original: Collecão dos Documentos, e Memórias da Academia Real da História Portuguesa, que neste ano de 1730, se compuseram, e imprimiram por ordem dos seus Censores. Lisboa Ocidental: Oficina de José Antonio da Silva, 1730, p. 1-18.

Para esta transcrição, decidiu-se por atualizar a ortografia enquanto a pontuação original foi mantida; também se decidiu manter a introdução da conta de estudos da reunião acadêmica na qual o discurso foi pronunciado, compondo dois pequenos parágrafos prévios ao relato. As citações latinas foram traduzidas e, por fim, as notas do original, escritas de punho do próprio autor, por serem em muito menor número que as notas adicionadas pela transcrição, são acompanhadas da indicação (NA), ou seja, Nota do Autor. As demais notas, fruto do trabalho de transcrição, não recebem quaisquer sinais gráficos.

1 "Narração das coisas passadas com louvor ou vitupério".

2 "Conhecimento dos particulares, dos quais a conservação da memória é útil a uma vida boa e piedosa".

${ }^{3}$ Vossius de arte Histor (NA). A primeira citação é do capítulo XVIII da Ars historica de Vossius, enquanto a segunda, do capítulo IV.
} 
verdade se escondera no fundo de um poço: In profundo puteo; o tempo, e a razão não puderam até agora deixar em pouca fé de lugar comum, o sentido figurado deste Filósofo.

Um dos maiores sinais da enfermidade humana é, que quanto mais nos estudamos em nós mesmos, mais nos ignoramos: quem mais pretende instruir-se da verdade das coisas, mais se desconhece; mais, ou menos conjectura, mais, ou menos imaginação, tudo é incerto, tudo é duvidoso. A História é mais sujeita a esta desgraça do homem, quanto mais inculcamos a matéria, mais a encobrimos ao crédito. Não sabemos por nós o que somos, e queremos saber por ela o que temos sido; não sabemos o que o Mundo é, e queremos ensinar o que o Mundo foi.

Os Historiadores fundam-se pela maior parte sobre acepções incertas, e vulgares, memórias defeituosas, e conjecturas atrevidas, de sorte, que não há Historiador profano, que não necessite de apologista sobre a sua verdade, porque além dos nublados, que a cercam, e obscurecem, tem ela contra si os afetos, e paixões de que é capaz o coração humano. ${ }^{4}$ Não se escrevem as coisas como elas foram, mas como o Historiador percebe que podiam ser, ou como the convém que fossem. Não põem a exatidão em descobrir a verdade, mas em formar a reflexão, que, ou a dissimula, ou a destrói[.] Quando um Historiador empreende escrever uma História, protesta logo sobre a sua verdade, afirmando haver escrito sem amor, nem ódio, fundado em bons documentos, e em boas memórias; se escreve uma História antiga, não deixa de fazer semelhantes protestos sobre a diligência de seu estudo, propondo com igual razão, que Tácito, e outros, que está despido dos referidos afetos, porque com o tempo, e com a distância faltou o temor, e a dependência. Todo o vestíbulo, por assim dizer, do Palácio da eloquência Histórica, está adornado de semelhantes pinturas de exatidão, e de fidelidade em uma, e outra História antiga, e moderna; e contudo da sua diligência, e da sua autoridade, não há caução segura, nem garante sua suspeita. Uns, e outros documentos, que hoje são antigos, e que também foram modernos, se escreveram, e compilaram por homens possuídos então dos mesmos afetos, e com a mesma suspeita. Não duvido, que do antigo todos queiram escrever a verdade, mas não podem, assim como do moderno alguns a podem escrever, mas não a querem; os modernos não são sinceros, os antigos não foram inspirados; em uns o interesse, e o amor da Pátria, e em outros o ódio, e a emulação da alheia, e em todos a ligeireza, e a facilidade da averiguação das coisas, lhes precipita o arbítrio, e lhes leva o juízo em seguimento do gênio. A verdade pois em a maior parte dos Escritores depende de sua reflexão, e de sua conjectura, e ela se propõe aos Leitores, segundo o humor em que estavam quando refletiam, ou quando conjecturavam, e em tudo parece o mesmo, o que é, e o que podia ser.

Tanto diferem entre si os Historiadores, escrevendo coisas, ou contrárias, ou diversas, que sem o socorro da opinião, e da preocupação de seu crédito, toda a narração ficaria sujeita aos termos da parte oposta. A causa desta variedade, e

\footnotetext{
${ }^{4}$ P. Rapin (NA).
} 
desta contradição, tem origem ordinariamente em os erros continuados, que se vão copiando de umas Histórias em outras, sem mais atenção, que à autoridade, que as apadrinha, e ao tempo que as recomenda.

Todos os Autores são estimados, e preferidos pela majestade do estilo, pela pureza das expressões, pela economia do discurso, pelo judicioso de frequentes máximas de estado, que eles nunca serviram, e do gabinete em que eles nunca entraram; e juntando-se a este caráter de gravidade, e de eloquência a dignidade da pessoa, e o predicamento de algum lugar, adquirem uma certa recomendação pública, que os constitui na maior prevenção de verdadeiros, e de fidedignos; contudo nenhum destes pomposos acidentes qualificam a verdade, segurando nelas a instrução da História para o seu atributo magistério da vida.

Não se duvide, que a História expõe aos olhos do Mundo grandes ações, grandes acontecimentos; é um painel, e um espelho em que cada um se pode enfeitar, e compor à sua fantasia; é uma lição comum para unir a glória, o interesse, uma arte para conformar gênios, e princípios, mas com muita diferença entre o mal, e o bem; mais exemplos fornece a verdade, para enobrecer o vício pelo aparato de grandes imitações, que para incitar a virtude pelo prêmio justo de grandes serviços. A natureza é tão fértil em maldades, que o pobre Historiador, ou há de mentir, ou há de perverter. Cícero propõe altamente ao Historiador esta tão proclamada liberdade: Ne quid falsi dicere audeat, deinde ne quid veri non audeat. ${ }^{5}$ Não se arrependeria este grande homem de haver escrito esta doutrina, mas poderia arrepender-se de a haver praticado: por ela 290 deixou a Cidade, por ela perdeu a vida, e o exemplo da sua morte fez a maior impressão, que a lição de sua doutrina. ${ }^{6}$

Se a Cronologia, ou doutrina dos tempos, se a Geografia, ou descrição da terra, são como dizem, os olhos da História, pode duvidar-se, que faça muitos passos com grande firmeza, e que não conduza seus Leitores a maiores precipícios; ao menos é certo, que nasceu sem olhos, porque uma, e outra disciplina teve seu princípio depois dela. Os jogos Olímpicos constituíram a primeira época, que entre os Gregos fixou, e mediu o tempo. Os Romanos depois de muitas, que eram comuns a toda a Itália, começaram a sua do tempo da fundação da Cidade: seguiram-se, ou concorreram outras, que não é necessário referir, porque falo diante de homens doutos, que as sabem melhor, que eu; porém também sabem, que em todas há tanta incerteza, e tanta confusão, como mostram desde seus primeiros Autores as obras últimas, e opostas de dois grandes Cronólogos o Padre Petavio, e Joseph Scaliger, aquele De doctrina temporum, e este De emendatione temporum. ${ }^{7}$

\footnotetext{
5 "[...] não ousar dizer algo de falso? Em seguida, ousar dizer algo de verdadeiro?", Cícero, De Orat., II, 63 (seguindo a tradição utilizada na apresentação a este texto).

${ }^{6} \mathrm{O}$ autor faz referência a dois episódios da vida de Marco Túlio Cícero. O primeiro é o exílio (58 a.C). que o orador romano é forçado a tomar após a ascensão de Júlio César; o segundo é sua morte, quando este opôs-se à ascensão de Marco Antônio por sobre o segundo triunvirato, passando a apoiar o jovem Otaviano, futuro imperador romano. A morte de Cìcero data de 43 a.C.

7 Joseph Justus Scaliger (1540-1609), uma das mais destacadas figuras da República das Letras no século XVI, foi um dos primeiros a adotar as cronologias babilônicas, persas, egípcias e hebraicas no interior da historiografia romana e grega. Denis Pétau (1583-1652), jesuíta francês, também foi cronólogo. Sua obra, De doctrina temporum (1627), gozou de bastante sucesso e foi considerada superior à obra de Scaliger, o $D e$ emendatione temporum, publicada em 1583.
} 
A Geografia não é disciplina de maior luz, a antiga desfigurada, a moderna suspeitosa; a primeira variou pela voracidade dos tempos, que consumiu Cidades, desviou rios, transplantou campanhas. A segunda copiada, e mal medida por observações vagas, e incertas na fé de viagens, que se escreveram como de caminho, por mais que se autorizem entre os Gregos, por Estrabão, e por Ptolomeu, entre os Latinos por Mella, e por Plínio, e entre os modernos por Hortélio, e Celário, ${ }^{8}$ e por mais amplos, ou corretos. De tudo que se conclui, que nestes dois grandes olhos da História a Cronologia, e a Geografia não há, nem muita perspicácia, nem segura condução. Só a História Sagrada é superior a esta incerteza, porque foi inspirada pelo Autor do tempo, e pelo Criador da terra.

Se lançarmos os olhos sobre as Histórias mais antigas, acharemos pouco, ou nada, que autorize com evidência, ou ainda que instrua com probabilidade. Omnis antiquitas fabulosa; ${ }^{9}$ seus Autores mais servem para a disputa, e para a erudição, que para nosso exemplo, e para a nossa cautela. Por pouco, que os Senhores Acadêmicos se queiram lembrar, convirão facilmente da incerteza invencível com que a História nos propõe as primeiras quatro Monarquias, que são o mais heróico, o mais respeitável objeto, que deve ocupar a contemplação do nosso entendimento, estudando os estragos da natureza, rebelde ao primeiro preceito, e o maravilhoso concurso da Providência na mesma alternada sucessão destes estragos.

A História da fundação da Monarquia dos Assírios, é tão escura, como antiga; a verdade acha como às escuras, tudo conjectura, tudo opinião. A sua dominação se conhece por vários nomes, ou para dizer melhor, se desconhece por muitos. Umas vezes é de Babilônios, outras de Caldeus, outras de Assírios. Dizem, que Nimrod fora o primeiro Rei, ou o primeiro Tirano; que Belus the antecedera; a Ninus sucessor deste se atribui a união dos Impérios Babilônico, e Caldeu, com a introdução dos Medos, que se dividiu em Saradanapalus, e que perdeu Balsazer, e tudo com tanta obscuridade, que mais nos admira a fama antes da lição, que nos instrui a lição refletindo sobre a incredibilidade da fama.

A grande monarquia dos Persas Elamitas, ou Partos, que melhor se conhece pela sua perda, que pela sua origem, começou em Ciro, e acabou em um Dario, dando lugar, por uma batalha, que perdeu, ao Império dos Gregos pela precipitada conquista de Alexandre, Império, que não passou da vida deste conquistador, ou deste usurpador do Mundo, cujas ações, começando pela fábula do seu nascimento, continuam com a mesma resistência ao crédito, e com tão rápido progresso, que mais exercitam a eloquência, e a maravilha, que animam a prudência, e instruem a razão de estado. A divisão deste Império

\footnotetext{
${ }^{8}$ Estrabão (63-24 a.C.), foi viajante e geógrafo da Magna Grécia, autor de uma Geographica, na qual descreve os territórios e os povos pelos quais passou; Cláudio Ptolomeu (90-168 d.C.) foi o principal geógrafo e astrônomo do período helenístico e suas pesquisas moldaram muito da compreensão do mundo pelos europeus até o início das navegações. Pompônio Mela foi o primeiro autor latino a tratar da geografia, escrevendo em 43 a.C. o pequeno tratado De situ orbis, suas investigações foram referenciadas nos livros III e IV da História natural de Plínio, o Velho, enciclopedista romano do século primeiro.

Abraham Ortelius (1527-1598), geógrafo flamengo, foi o autor do primeiro atlas moderno, o Theatrum orbis terrarum (1570), registrando já o Novo Mundo; Andreas Cellarius (1596-1665), foi geógrafo e astrônomo de origem alemã.

9 "Toda antiguidade é fabulosa", citação do livro II da Historia Philippicarum, de Justino, historiador romano.
} 
se propõe com igual obscuridade, e com igual indiferença, destruindo sempre os princípios da política, e da equidade. Os Egípcios, que por um séquito de Dinastias fabulosas disputam antiguidade do mesmo Mundo, ocupam o estudo, e a conciliação aos Cronólogos em matéria tão estéril, como inverossímil.

A última Monarquia dos Romanos, ou para dizer melhor, a primeira dominação, que se autoriza daquele grande nome, que começou em Reino, prosseguiu em República, e ultimamente em Império, traz consigo a mesma ambigüidade com igual descrédito da razão, e do verossímil. Não faltam Autores, que afirmem, que a grande guerra, e sítio de Tróia fora uma pura invenção Poética. Que Enéas nunca pisara o antigo Latium, e que menos, que exemplo de piedade à sua família, o fora de traição à sua Pátria. Que há perto de dois mil e quinhentos anos, que dizem florescera Rômulo, que se ignorava pela História a sua origem, a criação da loba, a ordem de Amilius, o comércio de Marte com a vestal Réia; uns dizem, que nascera em Grécia, outros, que em Síria, outros, que não viera à Itália. Que Roma fora edificada por uma filha de Italus, chamada Roma, e reduzida por Rômulo a maior povoação. ${ }^{10}$ É inútil prosseguir na incerteza da História antiga; pouco lhe falta para tirar do estreito as colunas de Hércules, para fechar este mar à navegação de Ulisses, e plantar no Setentrião o nome de Atlas.

Ordinariamente se acordam as Histórias dos estabelecimentos destas Monarquias (além do que se escreve na História Sagrada a diferentes fins da Providência) em alguns grandes fatos, como uma batalha, um sítio célebre, 292 uma conquista arrebatada, uma marcha bem conduzida, a morte de algum Soberano, alguma sublevação, alguma grande catástrofe; porém com tais circunstâncias, que tudo é indiferente ao crédito, e à instrução, com firme relação aos motivos, ao tempo, e à conjectura, e em tudo fica o Leitor, e o Político no arbítrio de sua imaginação, e nas mãos de seu conselho. Não só a História universal está cheia desta tenebrosa antiguidade, para nos inculcar as verdadeiras máximas daqueles ministérios, mas também as Histórias particulares, ou as vidas de grandes homens laboram na mesma indigência, e sejam exemplo as vidas, que escreveu Plutarco, que ainda que escritas judiciosamente, há nelas muita incerteza, e muita suposição, de sorte, que mais se produzem pelo juízo do Autor, que pela evidência da matéria, que outros Ihe contestam.

Se quisermos individuar um pouco a verdade, e o caráter dos Autores Gregos, que escreveram as suas Histórias, e as alheias, acharemos a mesma incerteza, e a mesma fábula: neles tudo passa a hipérbole, e pudera dizer a mentira:

Et quidquid Graecia mendax Audet in historia. ${ }^{11}$

\footnotetext{
${ }^{10} \mathrm{O}$ autor discute a coerência da lenda a respeito da origem de Roma, tal como apresentada no primeiro livro do $A b$ Urbe Condita, de Tito Lívio.

11 "[...] e [como] em toda a sua extensão a Grécia ousou mentir em sua história", citação da sátira X, versos 174-175, de Juvenal, poeta romano dos séculos I e II d.C.
} 
Nasceu esta omissão, ou desprezo pela verdade, de que seus Autores conseguiam o aplauso do Povo, lendo em público as suas obras, de que o mesmo Povo ignorante era Juiz circunspecto, e para conciliar o seu agrado, que era decisivo da reputação, e do crédito, estudavam mais a arte da composição, as sentenças, o decoro, a discrição, que entra melhor pelos ouvidos da gente: Ad scribendum se praeparabant, non studium veritatis exhibuerunt. Prometiam escrever a verdade, mas não verificavam a promessa: Licet haec promisso semper habeatur in promptu. Faziam pompa de palavras: Verborum magis habere prolationem. Mais se dispunham para captar o aplauso pelo elegante, que pelo verdadeiro: Ad hoc potius semetipsos aptabant. ${ }^{12}$ Daqui vemos navegando o Athos, Exércitos tão numerosos, que bebiam, e secavam os rios. As maravilhas, ou milagres da magnificência humana, que existiram, segundo as Histórias, discorrem pelos séculos tão encarecidas, que mais parecem sete invenções, que sete maravilhas; mais as desfigurou a História, que o tempo. É tão difícil unir a verdade à História Grega, que separar o homem do Historiador.

Homero, que igualmente fazem Historiador, que Poeta, mais brilha na ficção, que na verdade, mais no maravilhoso, que no natural; mais no prodígio, que na contingência.

Heródoto, o pretendido pai da História, escreveu com estilo suave, e elegante muitas coisas, que não sabia; e foi necessário, que passassem dois mil anos, para que em alguma parte se achassem certas. Não foi grande amante da verdade, ou entendeu, que não era necessária: em umas partes é parcial, em outras lisonjeiro, e não sei se venal em outras.

Tucídides, aquele admirado Historiador, que fez as delícias da Grécia em competência do famoso Heródoto, é eloqüente, e sentencioso, e muitas vezes escuro, foi notado de dissimular a verdade; senão a desprezou, omitiu-a.

Em Díon Cassius a parcialidade, a adulação, a maledicência não são grandes argumentos da sua verdade, e da sua boa fé.

Diodoro Sículo, ${ }^{13}$ que foi o primeiro, que entre os Gregos escreveu mais considerado, e atento, abunda tanto no fabuloso, e no inverossímil, que não deixou algum asilo à verdade, e alguma segurança no crédito.

Xenofonte, aquela abelha Ática, grande Historiador, e bom Capitão, em melhor das suas obras, e que lhe deu o grande nome na posteridade, compôs uma pura fábula, ou uma História inventada, que é a sua Ciropédia, ou a instituição de Ciro; ${ }^{14}$ e para dizer melhor, uma História, não do que Ciro fez, mas do que devia fazer; não é por tanto o melhor documento, e a mais segura imitação.

Todos estes Autores são igualmente suspeitos à verdade; as guerras que declaravam os seus Soberanos, ou os seus Magistrados, eram as mais justas;

\footnotetext{
12 "Preparavam-se para a escrita [da história], mas não buscavam com zelo a verdade, embora lhes fosse fácil prometer isso; [e sim] procuravam exibir seu próprio talento para a escrita. [E louvavam a si mesmos como se fossem estimados acima de todos] e preferiam adequar a si mesmos a isso", citação do livro I de Contra Ápio, de Flávio Josefo (37-100 d.C.), obra na qual o historiador judeu procura combater a visão grega acerca da história e da religião judaica.

${ }_{13}$ No original, Diodoro da Sicília.

${ }^{14}$ Cyropediam no original.
} 
as que Ihes faziam seus inimigos, as mais injustas. As suas conquistas sempre eram bem fundadas, as dos vizinhos sempre eram usurpações; se venciam, o valor dava a vitória; se eram vencidos, a fortuna. A religião, que tinham por verdadeira, sempre serviu ao estado, neles era sacrifício, em outros sacrilégio; se faziam paz, o seu Príncipe a arbitrava, o vizinho a recebia; se havia nela infração, era com causa, no vizinho com interesse. Finalmente sempre da sua parte a política, e o zelo dirigiam as maiores empresas, e da parte contrária o suborno, ou o destino.

Se fizermos uma curta recordação dos Autores Latinos, muito depois da fundação de Roma, acharemos os mesmos inconvenientes da inverossimilhança, ${ }^{15}$ e da maravilha. É certo, que depois daquela fundação, até que Roma foi rendida pelas Tropas das Gálias, em que passaram mais de trezentos anos, não há coisa, que instrua, e que segure o crédito; o governo dos Reis, dos Cônsules, dos Ditadores, dos Decem viri, dos Tribunos Consulares, das guerras estrangeiras, e intestinas, tudo é fabuloso, tudo é escuro: Res cum vetustae nimium obscuras velut que magno intervallo loci, vix cernuntur. ${ }^{16}$

A ação célebre dos Horácios, e dos Curiácios é escrita com tanta incerteza, que não se sabe quais destes irmãos combatia por Roma, quais por Albania. ${ }^{17} \mathrm{~A}$ ação famosa de Mucius Scevola é contraditada, e suspeitosa. A funesta empresa da Família Fabiana não é menos inverossímil, ou inventada. Um Valério pelejou, e venceu ajudado de um corvo. Cipião teve em seu nascimento por melhor prognóstico uma serpente. ${ }^{18} \mathrm{Em}$ tudo o maior cuidado era o prodigioso do 294 sucesso, e tudo o arbítrio do Escritor. Multa historici (diz Sêneca) ${ }^{19}$ mentiti sunt ad arbitrium. ${ }^{20}$ Flavius Vopiscus, ${ }^{21}$ que não é suspeito aos Romanos, escreveu na vida de Aureliano: Ne minem Scriptorum quatenus ad historias pertinet non aliquid esse mentitum; e entre o número deles não mete menos, que a Lívio, a Salústio, a Tácito, e a Trogo: ${ }^{22}$ Quos Historiae eloquentiae miramur authores. ${ }^{23}$

Fábio Píctor, o primeiro Escritor Romano, e que floresceu no tempo da segunda guerra Púnica, escreveu esta guerra com mais paixão, que verdade; não louvou os Cartagineses quando o mereciam, nem expôs candidamente o em que pecaram, devendo saber os sucessos, e causas daquela guerra, pois era Senador no tempo em que a escrevia, cuja má fé era tão indigna do Escritor, como do Ministro.

\footnotetext{
${ }_{15}$ No original, inverossimilidade.

16 "Coisas obscurecidas pela enorme passagem do tempo e também vistas como se estivessem a uma grande distância", livro 6 do $A b$ urbe condita, de Lívio.

17 No caso, Albania se refere a Alba Longa.

$18 \mathrm{O}$ autor se refere, neste parágrafo, a uma série de eventos e personagens dos primeiros séculos da história romana, retirados principalmente de Tito Lívio.

19 No original, Sênica.

20 "Muitos historiadores mentem a bel prazer", passagem do livro IV, capítulo 3, das Quaestiones naturales, de Sêneca, o jovem.

${ }^{21}$ Flavius Vopiscus é um dos seis scriptores a partir dos quais é compilada a Historia Augusta, uma coletânea de biografias dos imperadores romanos datada do século III d.C.

22 Pompeu Trogo, autor romana de origem celta, autor da Historia Philippicarum.

23 "Não há escritor de histórias que não tenha mentido" e, depois, "destes historiadores dos quais admiramos a eloquência", passagens do capítulo 2 da vida de Aureliano, retirado da Historia Augusta. A passagem toda é uma citação literal do texto original, incluindo as referências nominais aos historiadores romanos. Deve-se notar, porém, que comparado com as edições modernas, Brochado cita erroneamente em latim. As passagens corretas seriam: "[...] neminem scriptorum, quantum ad historiam pertinet, non aliquid esse mentitum. [...] 'quos historicae eloquentiae miramur auctores'".
} 
Tito Lívio, tão insigne Historiador como foi insigne Orador Cícero, sem faltar de alguma parcialidade, escreveu acontecimentos tão sobrenaturais, e encheu tanto a sua narração de prodígios, que a credulidade de visionário derroga nele a fé de Historiador.

Se em Salústio a eleição da matéria, a distribuição, e a eloquência fazem um agradável Historiador, o escuro nas expressões, e o desregrado nos costumes não Ihe conciliam, nem muita percepção, nem muito crédito.

Júlio César, que escreveu em grande Capitão, e em grande Historiador, voou tanto a sua pena, como a sua fortuna, e foi tão arrebatado em adquirir notícias, como em ganhar vitórias.

Em Patérculo, reputado por Autor popular, e de Corte, a pureza do estilo não Ihe purificou o ânimo de lisonja.

Quinto Cúrcio, ${ }^{24}$ que escreveu com pureza, e com elegância, desprezou a Cronologia, e a Geografia, ignorou o tempo, e os teatros da guerra, e apesar do crédito, que não devemos com facilidade a coisas que sucedem raramente, instrui aventureiros, e autoriza temerários.

As frequentes conjecturas do grande Cornélio Tácito, as altas penetrações do seu Arcanum Imperii, mais inculcam o seu engenho, que a sua verdade, mais apuram a Gramática do comentador, que seguram exemplos ao político.

Devemos contudo à História universal, tal qual ela é, uma prova mais da existência de Deus, e de sua Providência, porque nada in rebus humanis, ${ }^{25}$ indica melhor as operações da primeira causa, que a criação dos Impérios, Estados, e Repúblicas, a mesma divisão dos seus domínios, suas decadências, e transmutações, prêmios, e castigos, depois da infalibilidade da Escritura, em que só floresce a verdade sem nublado, sem paixão, sem, interesse, sem ódio, e sem ignorância.

Suposto que este breve discurso não passe da superfície da matéria, e de tal matéria, e não caiba maior disputa em a estreiteza de uma conta, sem abusar da paciência da Assembléia, é preciso deixar em repouso aos Autores, que escreveram as Histórias das Monarquias, e dos Estados, que presentemente existem; e assim não falarei da História geral da França, e não tratarei de inculcar a sua incerteza, e contrariedade, devendo começar pela primeira dúvida da sua fundação por um Faramundo, ou por um Clóvis, ${ }^{26}$ sem falar da eleição, ou da sucessão de seus Soberanos, aonde pela longa série de grandes Príncipes, foram tantos os acontecimentos, as guerras, as conquistas, as negociações, as

\footnotetext{
${ }^{24}$ Marcus Velleius Paterculus (19 a.C. - 31 d.C.), autor de um compêndio de história romana desde a queda de Tróia até sua época; Quintus Curtius Rufus, historiador romano do século I d.C., escreveu uma Historiae Alexandri Magni, muito lida na Renascença e na Idade Moderna. Era considerado modelo de estilo para a escrita histórica.

${ }^{25}$ Grotius de verit. relig. (NA). "nas coisas humanas", citação do De veritate religionis christianae, de Hugo Grotius, publicado em 1627.

${ }^{26}$ No origina, Pharamundo. O autor se refere à disputa acerca da veracidade dos documentos merovíngios, questão capital do debate erudito francês na segunda metade do século XVII. Daniel Papebrochius (16281714), editor dos Acta Sanctorum, compilação erudita da hagiografia cristã organizada pela sociedade dos bolandistas dos Países Baixos, escreveu na introdução ao segundo tomo do volume dedicado ao mês de abril uma condenação dos velhos pergaminhos franceses assim como estabelecia regras para sua validação ou descarte. A atitude de Papebrochius foi considerada hipercrítica e motivou amplas reações, dentre as quais se destaca a escrita, pelo beneditino maurista Jean Mabillon (1632-1707), do tratado De re diplomatica (1681), que assenta as bases da disciplina de análise e verificação de documentos antigos.
} 
contestações, e outras heróicas ações daquela nação belígera, que não seria muito, que a sua História não coubesse na compreensão dos seus Cronistas, para o rigoroso exame da verdade, quando vencessem sobre seu espírito a suave violência do afeto, e do interesse.

Com a mesma atenção deixamos na quase posse da sua verdade na História geral de Espanha, os grandes Escritores, que trabalharam nela, e correrá por conta da Crítica, que fez, ou prometeu fazer D. Nicolau Antônio, ${ }^{27}$ a fé que eles merecem, e que eu lhes não disputo.

As mais nações da Itália, de Alemanha, dos Reinos do Norte, e da Grã-Bretanha, ${ }^{28}$ tiveram tantos Escritores, que é inútil, e impossível o seu exame; eles se defendem, e se contradizem; uns escreveram com pena de prata, outros com pena de ferro, mas todos convêm, que ainda necessitam de maior luz, e de maior evidência.

Não se atreveria a mesma Cética a examinar a verdade dos nossos Historiadores, depois da judiciosa Crítica, que fez de suas obras, o Excelentíssimo Senhor Marquês Manoel Telles da Silva, no erudito Prólogo da História desta Real Academia, aonde perdoando-Ihes o estilo, e a credulidade os constituiu na autoridade, que mereciam. ${ }^{29}$

Se pois parece, que não há verdade na História, não será difícil mostrar, que para o fim da História não é necessária a verdade.

Ainda que a verdade seja o objeto mais natural do nosso entendimento, é necessário saber, que coisa seja esta verdade, se consiste na realidade 296 das coisas, se na verossimilhança ${ }^{30}$ delas, falo da verdade teoremática, e instrutiva. Quando as palavras se acordam com o pensamento, formam um discurso sincero; quando se acordam com as coisas, e com o entendimento, formam um discurso, ou verdadeiro, ou verossímil; ${ }^{31}$ sempre o nosso entendimento, e a nossa especulação tem por objeto a verdade, mas este objeto, que não entra pelos olhos, conforma-se com o verossímil, e com o provável, porque fica todo no crédito pela proporção entre as coisas, a imaginação, e o juízo.

Não vemos as coisas, que sucederam, vemos a sua probabilidade, ou a sua inverossimilhança, ${ }^{32}$ e esta é a verdade, que instrui, que ensina, e que entra pelos ouvidos, e pelo discurso, arrimada à razão, porque a este respeito: Verum est quod offenditur id quod est. ${ }^{33}$

\footnotetext{
27 Nicolás Antonio (1617-1684), erudito e bibliófilo espanhol, foi autor de duas obras bibliográficas nas quais discute os escritores espanhóis antigos e modernos. Sua crítica incide com especial agudeza sobre os chamados falsos cronicões, cronistas falsos cujas obras circulavam no ambiente intelectual espanhol visando a legitimação da monarquia castelhana e contando histórias fabulosas acerca de suas origens.

28 No original, grande Bretanha.

29 O Sistema especificava que os autores de memórias deveriam anteceder seus escritos elencando todos os autores utilizados no decorrer da investigação assim como fazer-lhes pequenos juízos críticos dos mesmos. Na História da Academia Real da História Portuguesa, primeiro livro publicado pela agremiação, em 1727, Manoel Telles da Silva antecede seu texto com um longo prefácio no qual revisa a historiografia portuguesa desde os primórdios até sua época.

${ }^{30}$ No original, verossimilidade.

${ }^{31}$ Grew. Cosmog. Sacra. (NA). Citação do livro II, capítulo V da Cosmologia Sacra, de Nehemiah Grew (1641-1712).

32 No original, inverossimilidade.

33 "A verdade é o que é". Trata-se de uma apropriação da frase vero est id quod est, citada nos Solilóquios de Santo Agostinho e trabalhada por Santo Tomás de Aquino no De Veritate, questão 1, problema 1.
} 
Se a verdade pois é uma conseqüência da coisa com o entendimento: Conformitas rei cum intellectus; ${ }^{34}$ neste sentido toda a verdade instrutiva consiste menos na existência das coisas, que na sua verossimilhança. In rebus antiquis, si quae família sunt, pro veris accipiuntur; ${ }^{35}$ e neste mesmo sentido pode a parábola entrar de igual passo com as Histórias, para o nosso ensino, e para a nossa cautela, e ainda com maior preferência, e com melhor uso. $\mathrm{O}$ honesto, e demonstrativo, o sentencioso, e o veemente, o louvor da virtude, a repreensão do vício influi com mais autoridade na parábola, que na História, porque seu Autor com maior independência, e com menos atenções não designa as pessoas, nem perverter os tempos.

Se as Histórias são escritas para instrução, e ditame, e que fazem passar em revista as coisas, que sucederam, também há Histórias, que estragam o ânimo, e que infectam a imaginação; e assim ainda que em algumas fábulas, ou novelas se ache o mesmo perigo, também há em outras muita lição e exemplo do vício punido, e da virtude exaltada. Não entram nesta virtuosa comparação as fábulas de Jablicus, de um Tatius, e outras, que se conhecem pelo título de milésias ${ }^{36}$ que contudo ${ }^{37}$ não excedem em número as Histórias, que correm com falso passaporte de verdadeiras.

A representação Histórica de Teágenes, e Caricléia, que escreveu o Bispo Heliodoro, e que Fócio louva, ${ }^{38}$ e recomenda, é escrita com muita imaginação, e com bom artifício, a frequência dos sucessos, a conclusão dos acontecimentos tão admiráveis, e judiciosos, repreendem o vício, e persuadem a conservação de uma das mais acreditadas virtudes.

A discreta, e judiciosa ficção de Argenis, que compôs John Barclay, ${ }^{39}$ é tão instrutiva, que um primeiro Ministro de França, douto, e purpurado, fazia na sua lição o seu não menos útil, que agradável estudo. ${ }^{40}$

Cremos, que a História de Jó é verdadeira, ainda que revestida de grandes ornatos de Poesia, e contudo aquela História na opinião dos que a supõem parábola, não é mais pregadora do sofrimento pela realidade, que pela contingência.

A mesma Ciropédia de Xenofonte, que se chama História, é uma fábula em que aquele Autor, como disse, não escreveu o que Ciro obrou, mas o que devia obrar: Cyrus ille à Xenophone non ad historiae fidem scriptus est, sed ad

\footnotetext{
34 "Conformidade das coisas com o intelecto".

35 "Em matéria de antiguidade, [desde que sejam semelhantes à verdade] então podem ser aceitas como verdadeiras", citação de Lívio, livro V, capítulo 21. A citação está errada; o correto seria: "Sed in rebus tam antiquis si quae similia veri sint pro veris accipiuntur", grifo meu.

${ }^{36}$ No original, milessianas. O autor se refere às fábulas milésias, gênero popular na Antiguidade que relatava histórias eróticas e de aventura; quanto aos autores, o primeiro é Jâmblico, autor de As babilônicas, enquanto o segundo é Aquiles Tácio, que compôs Leucipe e Clitofonte, ambos romances do século 2 d.C.

37 No original, com tudo.

${ }^{38} \mathrm{O}$ autor se refere à Etiópica, de Heliodoro, romance grego datado do século III d.C. A novela foi extremamente influente, tornando-se modelo da ficção em prosa nos séculos seguintes (em Bizâncio) e sendo redescoberta na Renascença (no Ocidente), servindo de modelo a Tasso e Ariosto, entre outros. Fócio (820-893) foi patriarca e compilador bizantino, tendo escrito a obra intitulada Bibliotheca. Junto com a Suda, outra enciclopédia bizantina, eram textos de referência tanto durante o medievo quanto durante a Idade Moderna,

39 Trata-se da novela política Argenis, publicada em latim em 1621 e, posteriormente, traduzida para o inglês. John Barclay (1582-1621), poeta, escritor e satirista escocês, trata nesta obra de um conflito de matizes religiosos entre Henrique III e Henrique IV da França, estabelecendo o paralelo - alegórico - com os problemas políticos da Inglaterra de sua época.

40 Papeblount Censur. Aut. (NA).
} 
effigiem justi imperii; ${ }^{41}$ de que se segue que para a moralidade tanto importa a verdade, como a semelhança. Não falo da História Eclesiástica, porque a este sempre convém religiosamente o verdadeiro trato da História profana, para cuja instrução basta moralmente o verossímil.

Os Árabes, ${ }^{42}$ e mais nações Orientais, que precederam os Gregos, e Romanos, e que foram os primeiros, que se serviram de fábulas, que chamamos Novelas, pretendiam, que tanto ensinavam com elas, como pelas Histórias, em que a verdade escura, ou desmentida era um débil documento para introduzir no ânimo o amor de bons costumes. ${ }^{43}$ Estas pois fábulas, ou novelas, que fizeram a primeira, e importante lição de toda a Ásia, e de toda a África, e que persuadiam tanto pela possibilidade que pelo sucesso, nos obrigam a crer, que para nosso ensino tanto importa, que as coisas fossem, como que pudessem ter sido, e assim pela dificuldade da sua evidência, como pela verossimilhança, ${ }^{44}$ nenhuma ofensa sensível fazemos ao culto, que se deve à verdade, pois escondendo-se na História a nossos olhos o seu original, veneramos na parábola a sua efígie.

A mitologia, ou mithistória, ${ }^{45}$ que é uma narração de fábulas, que fazia grande parte, e estudo da supersticiosa Teologia do Paganismo, como bem discursada alegoria investigava tudo o que convinha à veneração de seus falsos mistérios, e ensinava tudo o que podia instruir a escassa luz da razão humana. Platão na sua República assenta, que a primeira instituição, e lamentos doutrinais tiveram princípio na lição das fábulas honestas. Dionísio de Halicarnasso, ${ }^{46}$ que não é suspeito à verdade, diz: E Graecis fabulis non nullae sunt hominibus utilies; que toda a natureza se pinta 298 nelas, ou por elas: Aliaeque naturae opera sub allegoris contineant; que desvanecem os terrores do ânimo, e firmam nele a pureza de melhores opiniões: Aliae terrores animi a nobis depellunt, opiniones parum honestas destruunt. ${ }^{47}$

A utilidade pois das fábulas no melhor sentido de parábolas, em nada cede à lição da História; e sem me valer de maior autoridade, e de maiores provas sobre a fé humana, tiradas da lição Divina, bastam para o argumento deste papel as palavras de Sêneca, ${ }^{48}$ grande Mestre da doutrina moral; diz ele, que para demonstrar as coisas, eram de grande motivo as parábolas: Illi qui simpliciter, \& demonstrandae rei causa eloquebantur parabolis referti sunt; e que representavam como presentes as coisas, que propunham, e animavam: Discentem, \& audientem in rem praesentem adducunt. ${ }^{49}$

\footnotetext{
${ }^{41}$ Cicero. (NA). "Ciro não foi retratado por Xenofonte segundo a fidelidade à história, mas sim como imagem do justo império", citação da epístola VIII a Quintus, seu irmão, de Cícero, Ad familiares.

42 No original, Arabios.

${ }^{43} \mathrm{O}$ autor segue ao Traité de l'Origine des Romans, de Pierre-Daniel Huet (1630-1721), publicado em 1670, que localiza as primeiras fontes da ficção no Oriente, tendo passado dos árabes e persas aos gregos.

${ }^{44}$ No original, verossimilidade.

45 No original, mhythistoria. O autor se refere à mitografia, escrita, compilação e ordenação dos mitos antigos.

46 No original, Dionysius Halicarnasseus.

47 Liber I. rer. antiq. (NA). "Das fábulas gregas não é nula a utilidade para os homens, [...] e toda a natureza está nelas contida sob a forma de alegoria; todas as calamidades humanas encontram nelas consolação [lit. têm consolação]; todos os medos que atormentam nossa alma são debelados, todas as opiniões pobres em honestidade são destruídas", parece se tratar de uma citação das Antiguidades romanas, de Dionísio de Halicarnasso. A passagem também foi citada por Natalis Comes (1520-1582), mitógrafo italiano cuja compilação, as Mythologiae, foi muito lida durante a Idade Moderna. Em ambos os casos, infelizmente, não conseguimos encontrar as referências exatas.

48 No original, Senica.

${ }^{49}$ Sêneca, Epistolae morales ad Lucilium, LIX, 6-7. Trata-se de uma carta na qual Sêneca discorre sobre o prazer e a diversão e a passagem citada por José da Cunha Brochado argumenta a respeito do uso das
} 
Até aqui chega, Senhores, a relação de um paradoxo, como de um ponto duvidoso, que outros seguem e eu exponho, reconhecendo, que dele é resposta firme, e repreensão animada qualquer dos doutíssimos Escritores desta Real Academia, que pelos auxílios, e inspirações delRey, nosso magnífico Fundador, Protetor, e Mestre, conseguiram, não sem admiração do Mundo, ver no presente séculos por empresa, e por objeto de seus Instintos, a Verdade restituída, e a História revelada. 